\title{
Developing the Main Knowledge Management Process via Social Media in the IT Organisations: A Conceptual Perspective
}

\author{
Mohammad Waddah Hamoud ${ }^{1}$, Ali Tarhini ${ }^{2}$, Mohammed Ali Akour ${ }^{3} \&$ Zahran Al-Salti $^{2}$ \\ ${ }^{1}$ Faculty of Engineering and Computing, Coventry University, West Midlands, UK. \\ ${ }^{2}$ College of Economics and Political Science, Department of Information Systems, Sultan Qaboos University, \\ Muscat, Sultanate of Oman \\ ${ }^{3}$ Department of Management Information Systems, A'Sharqiyah University, Ibra, Sultanate of Oman \\ Correspondence: Ali Tarhini, College of Economics and Political Science, Department of Information Systems, \\ Sultan Qaboos University, Muscat, Sultanate of Oman. Tel: 974-5012-1922.
}

Received: August 16, 2016

Accepted: August 29, 2016

Online Published: September 2, 2016

doi:10.5430/ijba.v7n5p49

URL: http://dx.doi.org/10.5430/ijba.v7n5p49

\begin{abstract}
Development of main knowledge management via social media is one of the most important resource and effective strategy to gain the importance in IT industry around the world. Effective and proper knowledge management process allows the companies of IT industry to give the best effort in their business based on present resources. To the best of the authors' knowledge, there are few papers that review the concept of knowledge management and social media. Hence, this study aims to critically analyse the various models and theories related to knowledge management and social media for IT organizations. Fundamentally, the capabilities of ICT knowledge management process if developed via social media tools allow the organizations to identify the loopholes and develop proper strategy to remove it. Moreover, knowledge management has great impact on making strategy based on the resource. Involvement of social media tools in developing knowledge management process is more helpful and beneficial for any business organization as they can learn about the evaluation methods of online information into real life example.
\end{abstract}

Keywords: knowledge management process, knowledge management, social media, literature review

\section{Introduction}

Several researchers emphasize the role of Knowledge Management (KM) and its processes in achieving organizational competitive advantages (e.g., Barczyk \& Duncan, 2011; Altamony et al., 2016; Masada et al., 2015; Obeidat et al., 2016). The uses of knowledge management within the workplace, organization in business environment enable the organizations to achieve their strategic goals and effectively as well as efficiently sustain their business (Abbasi et al., 2015; Tarhini et al. 2015). Necessarily, in order to achieve the specific goals and objectives of the organization knowledge management helps in applying the collective knowledge in business performance (Koenig, 2009; Dalkir, 2011). It also helps in solving the problems and exploring the future growth opportunities (Al-Busaidi \& Olfman, 2005; Al-Salti and Hackney, 2011; Alenezi et al., 2015). Apart from that, Heisig (2009) argued in corporate sectors various forms and norms are highlighting the living standard. Knowledge management is the process that typically records the entire data for an organisation and helps in decision making for a particular organisation (Al-Busaidi et al., 2010).

Social media is one of the fastest growing technologies in these present days. Majority of people started using social media in their daily activities. The use of social media by policy makers in organizations allows them to access data and information easily and creates appropriate solutions to overcome the problems related to their business (Zheng et al., 2010; Al-Busaidi, 2010). Social media helps in updating the latest news about IT industry and its business process. Provide innovative techniques as well as service information for future successful development. Thus, social media is become an effective and integral part of knowledge management for organizations (Alalwan et al., 2016). On the other hand, knowledge management is also an effective process that enables the organisation in business sectors to develop proper and effective strategic plan based on the available resources (Kalkan; 2009; Masa'deh et al., 2016). Development of main knowledge management via social media is one of the most important resource and 
effective strategy to gain the importance in IT industry around the world. In the corporate sector majority of organizations uses knowledge management system in their workplace due to develop the business and success in future growth (Obeidat et al., 2016).

Based on the above discussion, this study aims to identify and understand the relationship of social media with the knowledge management in IT organisations by critically analyse the various models and theories related to knowledge management and social media for IT organizations. To the best of the authors' knowledge, there are few papers that review the concept of knowledge management and social media in the IT organizations. This study will be useful for both academia and practitioners as to fill the gap of the incomplete causal relationship between knowledge management and social media in IT organizations. Fundamentally, the capabilities of ICT knowledge management process if developed via social media tools allow the organizations to identify the loopholes and develop proper strategy to remove it.

\section{Concept of Knowledge Management}

In IT industry, majority of the organisations plays an important role in activating the tacit and explicit concept of knowledge. There are mainly four modes of spiral knowledge management processes such as socialization, combination, internalization and externalization.

\subsection{Knowledge Management Process Cycle}

The knowledge management processes cycle model provides the important and useful ways to the organisations in IT sectors to organize or making useful decision for business (Nusair et al., 2012; Al-Sarayrah et al., 2016). Lehner and Haas (2010) recognised that knowledge management process cycle models develop the good relationship of the knowledge detection and discovery, assessment and organisation, creation, sharing, refusing and the acquisition. The processes of knowledge management cycle are the valuable methods. It is accepted the terminology of knowledge management that makes the alternative paths for development and improvement in business of IT organisations. The several activities of knowledge management processes cycle play the key role and illustrate the major phases that necessary.

Creation - In the business process of an IT organisation, Creation creates the four modes regarding knowledge management processes. These are socializations, combinations, internalization and externalizations. Socialization is the method of tacit knowledge with the new tacit knowledge management process via shared experiences and social interactions. On the other hand, combination mode in knowledge management process with the help of merging creates new explicit knowledge for the IT organisations.

Internalizations are helps in converting the new tacit knowledge and create a explicit knowledge for the organisation regarding their business decision making process. Moreover, externalization mode helps in converting the tacit knowledge into the explicit knowledge. Maier and Thalmann (2010) argued that these four modes works accordingly to the apprentices and make the lesson learned survey reports through sharing and discussion.

Acquisition - Three major modes is present in the knowledge acquisition. These are search, sourcing and grafting. Knowledge management acquisition illustrates the various process of searching for new acquiring knowledge from the external sources. Sourcing allows to selects the proper sources from the external knowledge and make the decision for business of IT organisation due to future development. Grafting is the process of adding an individual process. According to Chen et al. (2009), grafting modes describes the individual process of desire knowledge to the IT organisations.

Refinement - Several modes are present in the refinement such as culling, encoding, distilling, explication, pruning, revising, etc. The modes of refinement helps the organisations in IT sectors and organized an appropriate format. This set of formats evaluate the explicit knowledge for the organisation in IT sectors. Apart from that, Cater and Cater (2009) argued various modes of refinement involved in business process in IT industry and doing better for the organisation. For example, culling helps in identifying the significant exemplars from the emerging markets. Distilling helps in creating the synopsis of the overall business process. Apart from that, organizing works better for the IT organisations, works for identifying the themes of recurrent, and makes an individual links with the knowledge.

Memory of knowledge management process involves in storing the knowledge for an IT organisation with the help of electronic repositories. Memory helps in storing the embedded business processes, relationship between the organisation and stakeholders and keeps the records of products or services.

Utilization - In each organisation in IT sector, required to transfer or share the data with stakeholders due to future 
growth. Utilizations, the methods of knowledge management process utilize the data via different modes such as infusion, elaboration, thoroughness, innovations, individual learning etc. Elaborations help in developing the various interpretations in order to growth of business. However, infusion helps the IT organisation in identifying the underlying issues and problems related to their business. Furthermore, thoroughness helps in developing the multiple understanding with the various groups or individuals.

\subsection{Knowledge Management and Learning in the IT Organisations}

\subsubsection{Significant Knowledge Management Consultants}

The influence of knowledge management consultants is very vital regarding the development of learning procedures and methodologies employed in IT organisations. Various significant educators emphasised on the system of thinking on processes and connections (Fugate et al. 2009; Al-Gharbi et al., 2009; El-Masri et al., 2015; Almajali et al., 2016). Some argued on the features of organisational learning procedures as the only effective media to understand the relation between the individual components that constitute the whole unit instead of studying the distinct sectors (Nusair et al., 2008; Holfve and Pekar, 2010; Masa'deh et al., 2016). There are certain views on single and double loop learning. The single loop learning is based on organisational activities, but does not provide any innovative ideologies. On the contrary, the double loop learning signifies the ability of critical thinking of distinguished persons within the organisation regarding different modules of learning technology.

Others do not seem to possess a positive attitude on the role of organisations to handle the knowledge in a skilful manner and relate the previous facts. It consider the limitations of organisations and portray the weak points of intricacies regarding certain factors such as hierarchical levels of infrastructure, human attitudes and behaviour, work culture and different descriptions of procedures and so on (Barczyk \& Duncan, 2011). Some significant knowledge management are consultants rely on the impact of leadership qualities on organisational loopholes and develop suitable tactics to manage the organisational goals and objectives. The leaders can direct the road to success by means of certain changes in different steps of the processes of knowledge to indulge the eagerness and develop a positive strategy (Chen et al. 2009).

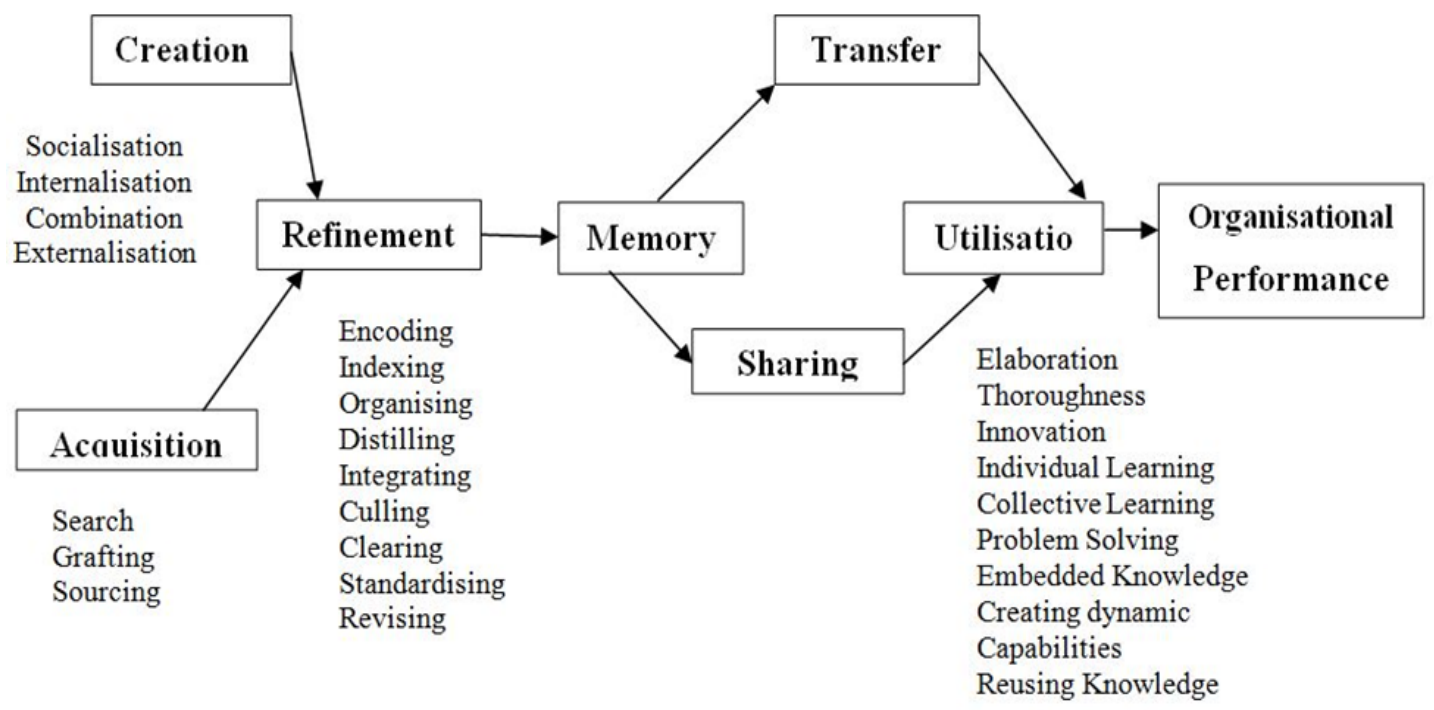

Figure 1. Knowledge management process model (Source: Barczyk and Duncan, 2011)

There are certain expertises who advocate distinct opinions on the function of management in relation to learning. These educators argue that the most significant methods of learning are the ones that cannot be modified and handled. They give importance to chaos theory that draws attention to some sort of confused states of information technology and non- linear concepts of networking (Chu et al. 2012). There happens to the need of the interference of staff to fill up the gaps of incomplete data and rely on own set of justifications and build a formal structure with the inputs taken from informal source. 


\subsubsection{Information Age Workplace}

The challenges of information age are very effectively solved by the different organisations and business sectors. Knowledge and information are two important concepts to run a business unit in a new and innovative manner. According to modern technologists, the traditional system of monitoring the inputs and outputs are no longer applicable to compete in the present world (Fischer and Reuber, 2011). The organisations have a tendency to develop fruitful strategies to facilitate internal sharing of communicating resources in order to stand as distinct entities in the real world. This is generally termed as knowledge sharing as coined by the technologists of the earlier years. Their goal was to improve certain aspects of knowledge based on information systems and technological advancement (Ractham and Firpo, 2011).

The next generation of knowledge management concepts give stress on certain other factors that is more significant in terms of business development strategies. The idea of anticipation of implementation of certain methodologies proves to be better than the principle of prediction. The management theory of acceptance is gradually changing to the ideology of self-reliance and self-organisation (Holfve and Pekar, 2011; Masa'deh et al., 2015). The modern postulates of business plan give importance to formation of unique ways of learning from the knowledge already gathered from experiences (Zheng et al. 2010). The application of computer systems to develop certain processes based on the principles of knowledge management.

The transformation of an existing system to newer forms depends on the nature of the business enterprises. According to Chen et al. (2009), there are different patterns of organisations that depend on the values of business processes, effective utilisation of appropriate systems, arrangement of types of network and the level of competence to stand among different competitors. The individual capabilities of the members of a functional unit hold significant reference to develop and analyse the facts of observation and draw the relevant inference based on the justified statements. Neto et al. (2009) the models of network vary according to the design and setting of information systems and henceforth require eligible team of professionals who can easily cope up with all kinds of circumstances and adapt the innovative ideas of processing technologies. This enables smooth and accurate formation of the structure of knowledge.

\subsection{Performance Measurement}

Knowledge management process and its models are very much useful for any kind of business process (Porumbeanu, 2010). The major concern of knowledge management is providing the actual value of business's production or manufacturing process and prove it with proper justifications. For example, an organisation in IT sector implementing the knowledge management process can understand the external demand of the customers. From the stored information, they can provide service to their customer and make appropriate decision for future development and business profits. According to Maier and Thalmann (2010), knowledge management process provides the traditional accounting as well as measurement system to the organisation especially to the IT organisations.

However, traditional system has some significant problems. Traditional system works with the tangible inputs and outputs. It never works with the knowledge of intangible assets. Traditional system is also intended to emphasize the costs of business for IT organisations. Apart from that, various organisations in IT industry implement the knowledge management processes due to increase the work efficiency and profitability as well as sustainability. Accounting and measurement system of knowledge management process not only allow in capturing the potential increase rate of production but also it helps in increasing the intangible assets and the strategic advantages (Arazy et al. 2009). For example, the company Skandia implement the knowledge management process within their business. Moreover, the company also appointed a director of intellectual capital. It allows them in compiling the present matrices indicators with the annual reports. It increases the work efficiency and profitability for Skandia.

In addition, later traditional measurement system focused on the assessing the matrices of knowledge management process and oriented the measurement models significantly. Such kind of model of performance measurement helps in providing the corrective action during the production process and makes the business process efficient. Apart from that, Fugate et al. (2009) acknowledged performance measurement of knowledge management process allows the IT organisation to measure the performance of worker individually and helps in creating the right path of efficiency.

\subsection{Boisot's Knowledge Category Models}

Boisot established this model in 198. It considers the knowledge either codified or un-codified. The term codified helps in preparing the knowledge for transmission such as the financial data. However, codified helps in un-diffusing the proprietary knowledge and transmit the data or share within a small group of people. On the contrary, un-codified refers that knowledge management process is not able to prepare the purpose of transmission. Apart from that, this 
model suggests the knowledge of un-diffused and un-codified and it refers to the personal knowledge.

However, Boisot's Knowledge Category Model (see Figure 2) diffused and un-codified the knowledge and develop the important process of externalization and socialization (Ractham and Firpo, 2011). Moreover, Boisot's Knowledge Category Model suggests that knowledge diffusion reflects the dimension of knowledge horizontally within the IT organizations.

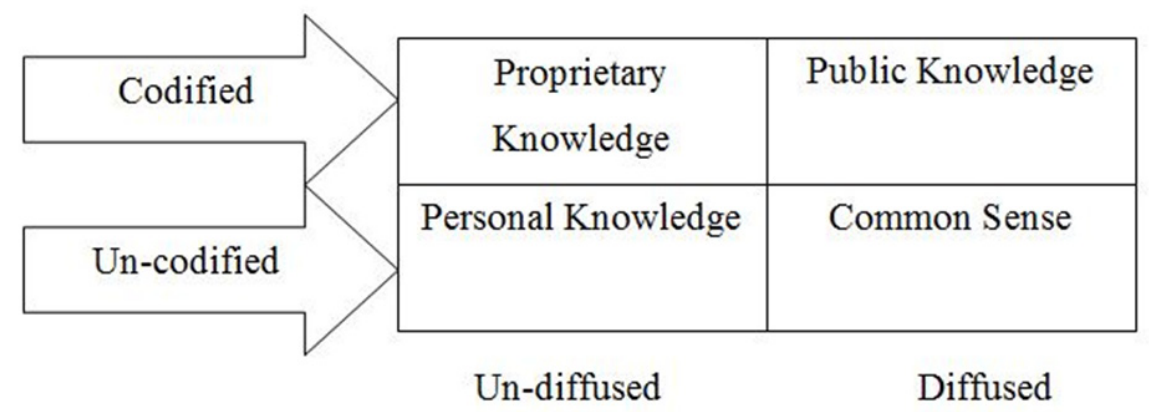

Figure 2. Boisot's Knowledge Category Model (Source: Ractham and Firpo, 2011)

\subsection{ADAM's Model}

In business process of IT organisations ADAM's model helps in understanding the details of trade-off between the E-learning perceptions and the users. This model is based on the knowledge management information sensitivity. However, ADAM's model is used in business process of IT organisations in order to evaluate the several applications of E-learning such as video conferencing, virtual reality, e-resources etc.

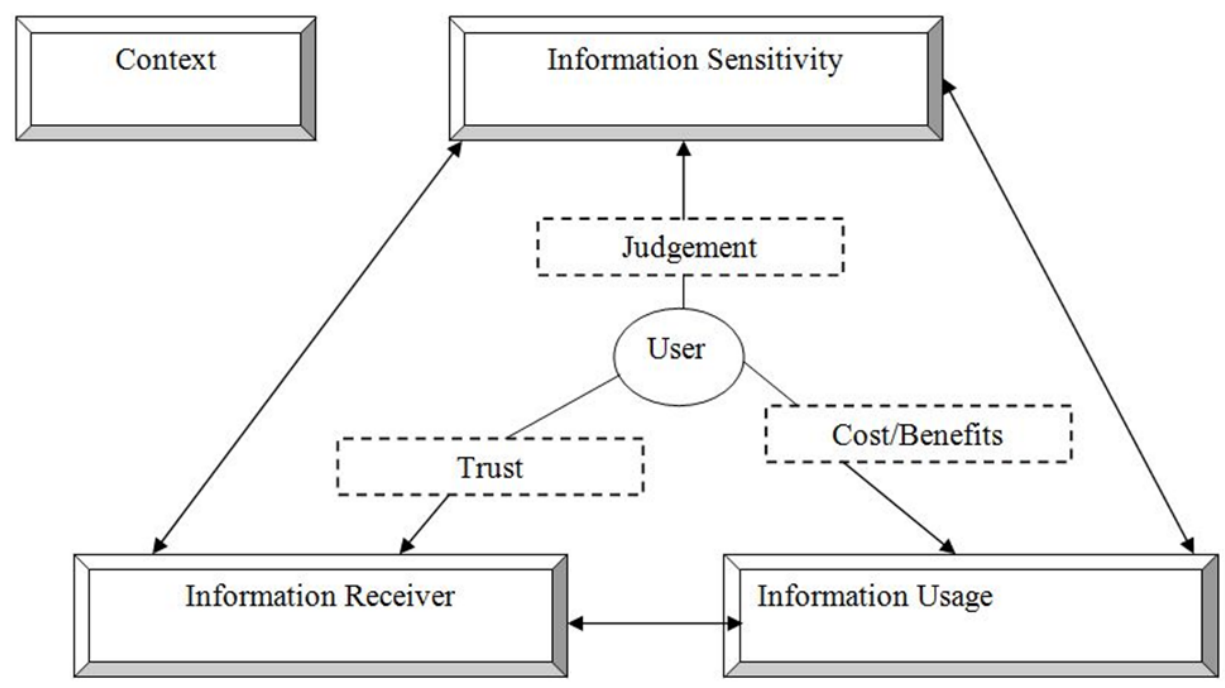

Figure 3. Adam's model of knowledge management (Source: Neto et al. 2009)

This model allows the company in IT industry to transmit the data with stakeholders and make appropriate solutions for business. For example, most of IT organizations in the world use ADAM's model in their knowledge management process due to interact with the stakeholders for sharing or interacting with them. It helps them to make better decision for future development.

Neto et al. (2009) stated that, the users of Adam's model is never used the system actively. They are always unaware about the transmission of data. Primary method of Adam's model is the concept and philosophy of information 
sensitivity. It allows the users for perceptions about the data transmission confidentially. If the users aware about the data transmission, they can firmly percept the external resources and uses it confidentially for business improvement. Moreover, Coakes et al. (2010) argued that user's judgement in the level of information sensitivity are the binary. For instance, it may be the private or not.

On the other hand, Chen et al. (2009) stated that user's judgement at the information sensitivity level are multi-dimensional. It indicates that the users send or receives the data to others and able to manipulate the data based on the external resource perceptions. This process is called the information receivers. On the contrary, when the users perceived the used data for sharing or collecting information the process will be information usage.

Moreover, the context technology of Adam's model enables its users to understand the issues related to business (Holfve and Pekar, 2011). For example, within the knowledge management system, Adam's model makes a virtual reality context. It enables the anonymous information for business development in future at IT organisations.

Maier and Thalmann (2010) mentioned that, all the factors helps to interact the contextual issues from the overall perception of trust, sharing potential and privacy. For example, organisations in IT industry trust their consumers but never invade their information with the customers. On the other hand, Fugate et al. (2009) recognised that virtual environment of Adam's model provides the benefits of remote location that enables the farm in business sectors for collaborating with the stakeholders and share the artificial environment information with them.

\subsection{WIIG Model for Building and Using Knowledge}

Karl Wiig develops the WIIG knowledge management model for using and building the knowledge. There are present four key principle of this model such as completeness, connectedness, congruency and purpose and perspective. Lehner and Haas (2010) stated that these four key elements make the knowledge management system more valuable and useful as well as powerful. On the contrary, Neto et al. (2009) argued that these principles help in organizing the knowledge management process within the business of IT organisations.

However, WIIG model is helps in defining the different levels of knowledge management process of internationalization. Therefore, it is also the further refinement of knowledge spiral for internationalizations. The span of internationalization level is classified into different modes such as expert, novice, master, and beginner and competent. A novice mode of WIIG model is unaware about the available knowledge within system and do not know to use it.

A beginner know the available knowledge within system but do not know about the reason of exist. Competent understand the available knowledge and documents it for helping the people. Experts help in holding the knowledge into memory and understand about the exact place for applying. Apart from that, Coakes et al. (2010) acknowledged the process of WIIG model maintain a hierarchy of knowledge where consists the forms of public, personal and shared knowledge. However, each form involves four type of knowledge management system such as exceptional, methodological, factual and exceptional.

Completeness - Chen et al. (2009) highlighted that completeness of WIIG model is help in identify the related available knowledge from the external sources. The sources might be tacit or explicit knowledge. It varies from human minds to base of knowledge. Completeness tools of WIIG model first assures the available knowledge and then completes the knowledge with the help of entire available information.

Connectedness - The term connectedness of WIIG model denotes the well defined and well understands of relationship between the different objectives. Most of objectives in knowledge management system connected with each other coherently (Chu et al. 2012). It provides the greater value to knowledge base.

Congruency - in order to judge the links between different objectives congruency discussed the entire facts, values, concepts and perspective of knowledge base. However, majority of content does not meet with the knowledge base details.

Purpose and Perspective - This phenomenon helps in justifying the particular point of view due to specific purpose. Purpose and Perspective helps in organizing the dual dimension of knowledge base on knowledge management process.

\subsection{The Choo Sense Making Knowledge Management Model}

In knowledge management process, Choo Sense Making Knowledge Management Model is mainly focuses on sense making, decision making and creation of innovative idea for business in IT industry. According to Choo (1998), in order to know the organisation in better way and make it sustainable, need to use of information strategically. Foe knowing the organization three areas has to focus such as creation of knowledge, decision-making and sense making. 


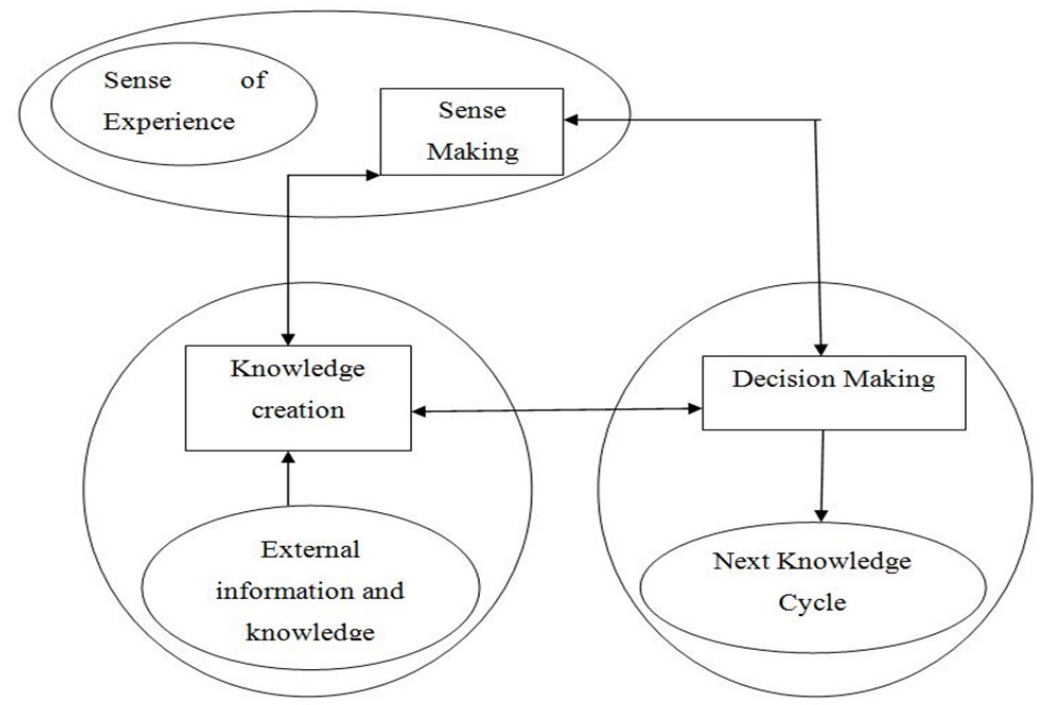

Figure 4. Choo Sense Making Knowledge Management Model (Source: Choo, 1998)

These three elements are highly inter-connected and play the key strategic role in enfoldment of knowledge vision of IT organisations. However, these are playing the potential role in knowledge creation and have the great commitment on consequence decision making. Moreover, there are many inference of decision-making theory but few of them are strongly highlighted such as:

- The process of decision-making is driven via searching. It provides the alternatives path that good enough and satisfactory. Furthermore, decision-making process helps in seeking the optimal solutions.

- In the emergence of costs and trade off single alternatives implies in concomitantly.

- Decision making process provides the complete decision about the required information. In order to execute the information process of human capacity requires.

As stated by Fugate et al. (2009), the process of decision making execute the action of success for organisations in IT sector.

Sense Making - Sense making concern the long-term goals for IT organisations. Sense making provides the information within knowledge base to the organisations to adopt and continuously run in a dynamic way. Moreover, the activities of sense making interpret with the complex environment and enables in understanding the possible changes in business for future development. However, sense making helps in understanding the scenarios and trends of the customers and suppliers in business. Coakes et al. (2010) stated that sense making of knowledge management reduce the uncertainty and manages the ambiguity.

Knowledge Creation - In knowledge management process, knowledge creation process allows in creating the information that generates the new knowledge learning methods. New knowledge generates the new abilities and new capabilities for the organisations due to create new service and products. Moreover, it improves the existing service in IT industry. Chen et al. (2009) argued that in IT organisations, knowledge creation redesigns the overall processes.

Decision Making - This process is the most important in knowledge management model. Through the decision-making organisation in IT industry, can choose the appropriate option for future development (Neto et al. 2009). Moreover, in an IT organisation decision-making process constrained through the rationally principle.

\section{Concept of Social Media}

As stated by Anderson (2009), social media allows the users to describe and share the content over websites. There are various popular social media networking websites such as Facebook, Twitter, MySpace, Friendster, etc. In order to share video and photo easily and quickly, social media network also includes Flickr, Picasa, Photobucket, You Tube, etc. However, in relation to share the news and various online resources different websites such as Wikipedia, Webopedia, Digg are involved in social media networking. Apart from that, it has been seen that Google purchased YouTube that is called the world largest video streaming website (Zheng et al. 2010). 


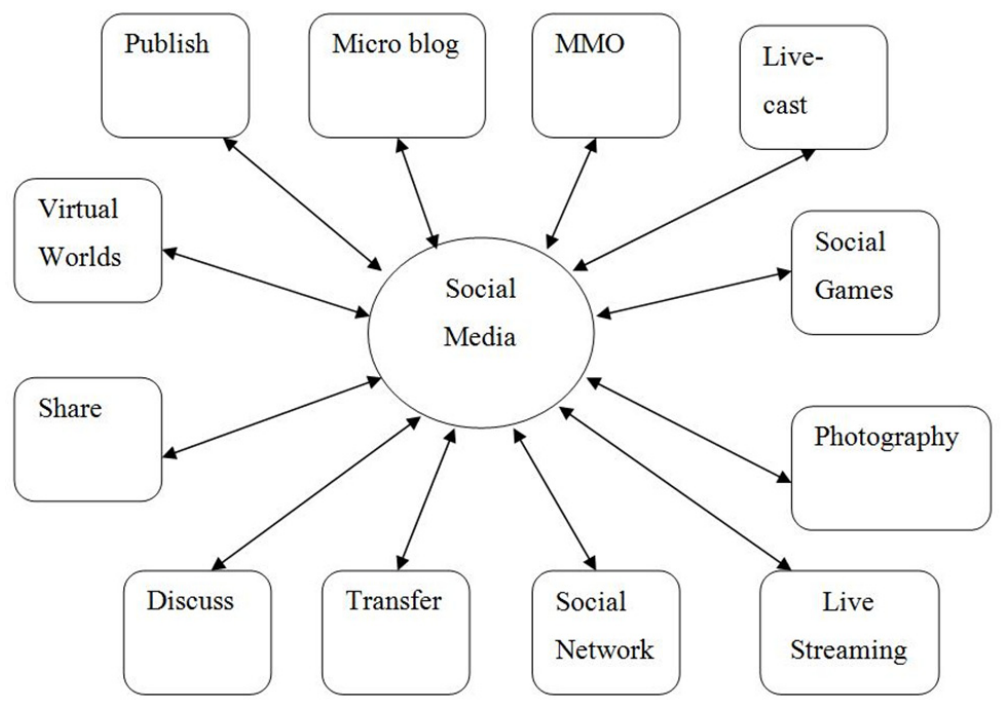

Figure 5. Overview of social Media (Source: Anderson, 2009)

\subsection{Social Network Analysis}

In the business process of IT organisations, due to the development of knowledge management processes, the theory of social media network allows the owner of the company in getting an individual idea from the connected actors (Holfve and Pekar, 2011; Al-Dmour et al., 2016). Through social media, the IT organisations are able to develop knowledge management process using the various mathematical models and structure. Social media also allows the IT organisations to evaluate the process in the right way and develops the system accurately (Donovan and Henley, 2010).

In a community, social media analysis treats the actors individually and develops a good relationship between the organisations and communities. However, Contractor (2009) recognised that social media formed at different levels such as communities, nations, families and individual people. It allows the organisations in IT industry to communicate with each other and exchange the idea as well as financial, etc. Due to development of knowledge management system, social media helps in understanding the best way of developing along with its benefits and demerits in the business case.

Apart from that, $\mathrm{Li}$ (2010) argued following are the mathematical calculation of social media network in order to develop the knowledge management system in IT organisations.

- The social media network allows the nodes to connect with each other and perform closely. This process is called closeness.

- The social media network makes possible the all ties such as community, nation, family and individual within the network.

- The extent of one node is present between the gaps of two nodes.

The above mention mathematical calculation demonstrates the positions of structural and importance individually. However, the given calculation of social media network improves the network structure. This is helpful for developing knowledge management process in IT industry (Barczyk and Duncan, 2011). Minimization of gap or loophole indicates the incarceration rate of efficiency for developing the knowledge management system. In relation to measure the indices within the social media network one network analysis software is present such as UCINET.

Apart from that, Arazy et al. (2009) indicated that the traditional social media network analysis demonstrates the organisational structure as a node within the network. Moreover, Brzowski et al. (2009) argued that social media is the solidification and materializations of comments, chatters, review, etc. In the current scenario of IT business, the framework of multidimensional social media network is important and much crucial (Arazy et al. 2009). It allows the owner of IT organisations to interact between the information artefacts and the social media users. Using the social media network, IT organisations is able to interact with the communities and perform their mathematical calculation for developing knowledge management system. For example, IT organisations can understand the important pieces 
based on sharing ideas of many people.

According to the theory of Chen et al. (2009), the transmission of rumour in social media network defines the speed and accuracy that mostly affected in the network. However, this theory allows in understanding the mental sets of users within social media network. Connecting the rumour transmission to online social networking websites informed the IT organisations in business to use the best methods of developing the knowledge management system and promoting the organisation into the word-of-mouth (Carter and Carter, 2009). On the other hand, recently different application of multidimensional social network analysis helps in generating faithful result for business organisations.

\subsection{Social Penetration Theory}

Altman and Taylor have proposed social penetration theory in 1987. This model is help in developing the better relationship between organisations and communities. This theory provides different way where organisations in IT industry communicate with other. Social penetration theory mainly focused on the dyadic and individual levels in relationships. However, this theory aggregates the organisational level due to the development of knowledge management system.

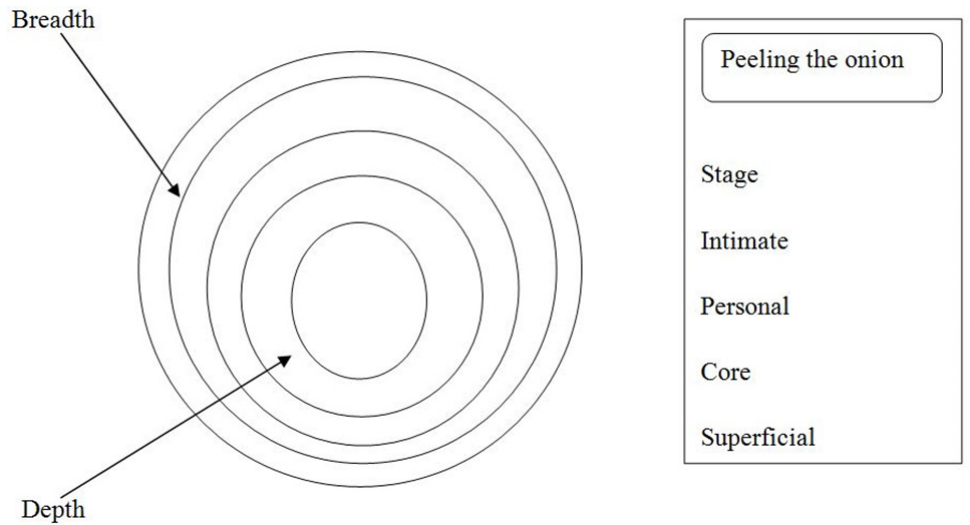

Figure 6. Social Penetration Theory (Source: Bohnert and Ross, 2010)

Social penetration theory, using the peeling off layers runs the process continuously and helps the IT organisation in identifying the benefits as well as the demerits of knowledge management system. As argued by Bohnert and Ross (2010), social penetration theory allows the organisations to start with the visible, public and the information on superficial such as the advantage of DBMS (Data Base Management System), DSS (Decision Support System) etc and allow in choosing the best knowledge management process according to organisational behaviour.

Moreover, social penetration theory allows the organisations in IT industry to progress the relationship with external environment slowly and enter into the deepest level. Furthermore, Broughton et al. (2011) stated that social penetration theory could design the best social network for IT organisations in online social world. It separates the different layers of information. With the help of social penetration theory, certain important information can be disclosed for the public due to the development of knowledge management system via social media. Apart from that, social penetration theory helps in determining the different levels of relationships of communication frequency and mode of operations in online social website (Zheng et al. 2010). For example, recently it is identified that privacy of lawsuit in Facebook highlighted the various importance such as the layered of intimacy levels of social penetration theory. It discloses the private information.

Moreover, Brown and Vaughn (2011) argued that, social penetration theory of social media network helps in penetrating the deepest relationship into personal and private matter for the organisations in business sector. It indicates that trust will be developed and exposes the vulnerabilities. According to Chamberlain (2012), in online social websites penetration goes through into different level such as affective level, exploratory affective level, sable level, orientation level, etc.

Affective Level - In this level, social penetration theory starts to work with the personal and private matters. Penetration uses different idioms in this level. Several arguments as well as criticism arise in this stage. It sometimes 
touches the intimation level of online social network.

Exploratory Affective Level - Here, social penetration theory start to express the personal attitude about the development of knowledge management system via social media in IT organisations. This might be truthful or not. Sometime it comforts for IT organisations and sometimes its lat bare. In this stage, social penetration theory allows the organisations in IT industry in bringing the good relationship with community.

Stable Level - In this level, social penetration theory moves the relationship into personal things where people can share their views and ideas related to development of knowledge management system in IT industry via social media. Moreover, CIPD (2013) stated that, social penetration theory in online social websites predicted the reactions of emotional of one person.

Orientation Level - In this level, social penetration theory allows the organisation in playing the safe role (Brzowski et al. 2009). The forms of norms of appropriateness and the standards of desirability of social media network can play safe and talk simple.

\subsection{Social Exchange Theory}

In online social websites, the entire social media network depends on the providing content by the users. Moreover, social media network is depending based on the fundamental of user's motive and understanding. The theory of social exchange originated the studies of social exchange and its exploring with the users of social media network and organisations in IT industry. The theory of social exchange is used by the organisation in corporate sectors for developing the framework of cost-benefits. However, it provides the various alternative ways of communicating with the community (Zheng et al. 2010). Social exchange theory helps in understanding the bonds and relationships between business farm and community in corporate sector. Moreover, social exchange theory demonstrates the entire scenario of communities and its forms through the exchange of communication.

On the other hand, the behaviour of social exchange theory contributes the assessment of cost benefits in social exchange and successful development of knowledge management system via social media in IT organisations (Arazy et al. 2009). Implementation of social exchange theory in development of knowledge management system, organisations in IT industry can communicate or exchange the contingent actions (Barczyk and Duncan, 2011). However, it allows in analyzing the mutual reinforcement via the framework of micro-economic. In order to development of knowledge management system in IT organisations, social exchange theory provides the monetary rewards such as conformity, opportunity acceptance and prestige.

Apart from that, Clark and Roberts (2010) argued that, social exchange theory is a behaviour of social media that allows in exchanging ideas, views, opinions etc. In IT industry, social exchange theory gives the director of organisation to share the view about development of knowledge management system and its benefits in business. This process influence the work tends of IT organisations and generates the equilibrium to the exchange balance. However, in business of IT organisations, social exchange theory gives the framework of cost benefits and changes their behavior.

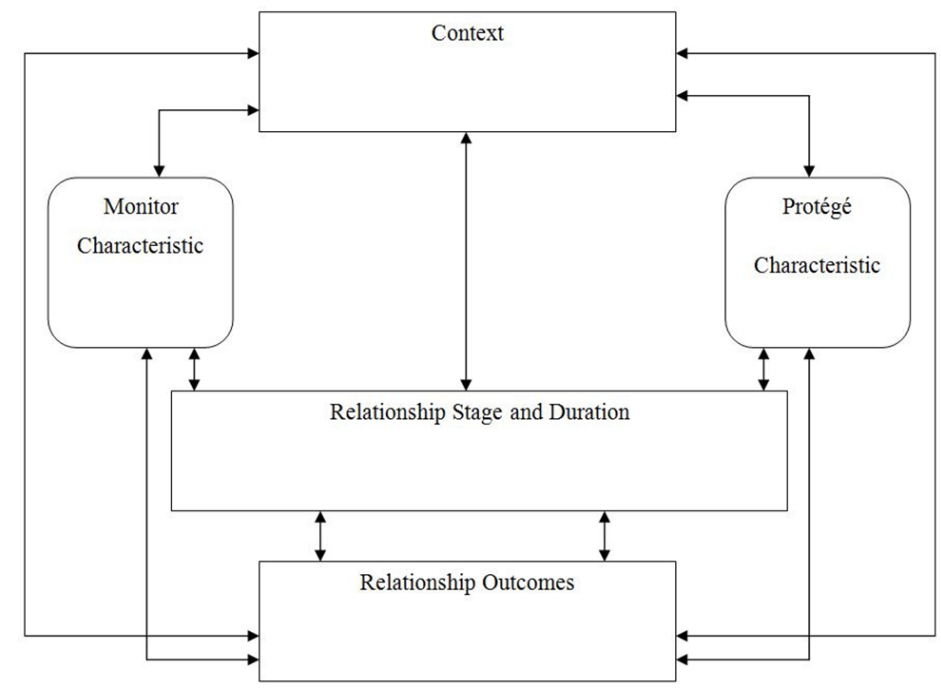

Figure 7. Social Exchange Theory (Source: Clark and Roberts, 2010) 
This is the reason of engagement social exchange theory in social media. It proposed the best way of implementation new IT system in organisation. Social exchange theory gained the reputation of IT organisation and influence to implement the knowledge management system in business process.

In addition, social exchange theory helps in testing the validity and implementation benefits of knowledge management system in IT organisations. Social exchange theory provides some important hierarchy of the views of users related knowledge management system (Ahmed et al. 2010). Moreover, the theory of social exchange seeks the information and engages it in making an affective knowledge management process in business of IT organisations. In addition, the organisation in IT industry is able to share the ideas with social media networking users and make their development process of knowledge management more useful.

The process of sharing ideas makes the organisations in IT industry to simplify their development process of knowledge management and forwarding the content. For example, Facebook gives the facilities of open graph where users can like and comment. This method firmly gives the advantage of developing process proactively.

\subsection{Pseudo Theories}

Social media network is the fastest changing landscape in this world. According to Davison et al. (2011), social media landscape is the innovative idea that execute in low cost as well as the era of social media is open source. People can share the ideas over social media network and get the relevant idea for individual activities. In business process, generally it is identified that long distance becomes the major problems. The IT organisation faces many challenges to serve better to the consumer and communicate with the stakeholders.

In addition, IT organisations willing to develop the knowledge management process in their business (Kaplan and Haenlein, 2010). Social media will be the affective tools of developing knowledge management in IT organisations. Social media allows the company to interact with communities in low cost and get the relevant and useful information for development of knowledge management system (Arazy et al. 2009). Social media reduce the slow process and minimize the challenges that faced by the company. Through the social media network, IT organisations get the actual and innovative idea for development of knowledge management system (Barczyk and Duncan, 2011). Here, represent the two frameworks such as social-graphic framework and framework line of social media landscape for making the sense and demonstrates the usefulness.

Social-graphic Framework - The major contributors of social-graphic framework are Altimeter group. However, Kaplan and Haenlein (2010) argued that in order to develop the business successfully, knowledge management is the best way. Social media will be the better strategy of development of knowledge management system rather than demographic, psychographic, geographic etc. The managers and the marketing directors of IT organisations has to understand the social websites where people pay their attention most. Social graphic is the major contributor of developing social media theory in social network. Moreover, they have to identify the engagement of sharing data, producing, commenting etc.

Line of framework - This strategy allows the managers of IT organisations in linking with the community and collects the relevant information. Apart from that, Leonardi (2009) indicated that the line of framework provides the three stage of traditional funnel such as considerations, purchase and awareness. It influences the IT organisation in decision making for development of knowledge management system in bringing the speed in business. Moreover, this tool allows the IT organisations in making the concept of developing knowledge management system and treat after implementation. Use of social media allows the IT organisation to find out the results and some experience of using knowledge management system in business. This feedback cycle method drives the benefits for developing knowledge manage system in IT organisations.

On the contrary, these two frameworks affect on the development of knowledge management via social media network. Use of social media network allows the IT organisation about the required framework for implementing knowledge management process (Chen et al. 2009). Moreover, the frameworks of social media network specify the exact methods developing knowledge management system. These two frameworks of social media network also influence the ways of post consumption of knowledge management.

\subsection{McLuhan's Media Theory}

The great Canadian philosopher and educator proposed a famous quote in 1995 that the media is the message (Chen et al. 2009). According to Alessandro and Ralph (2009), media is able to transfer the content to community and society rather than actually and individual. Media allows the organisation in communicating with the nations and people and interact the frequency of new communication pattern. 
In addition, Ahmed et al. (2010) argued that media has an emerging affect on society as well as business. Marshall McLuhan separates the media into two different categories such as hot and cool media. In order to exert the viewer effort IT organisations need to understand the benefits of several media content such as cartoons, seminars, television etc. It helps the managers and directors of IT organizations in making a sense of developing knowledge management process within their business.

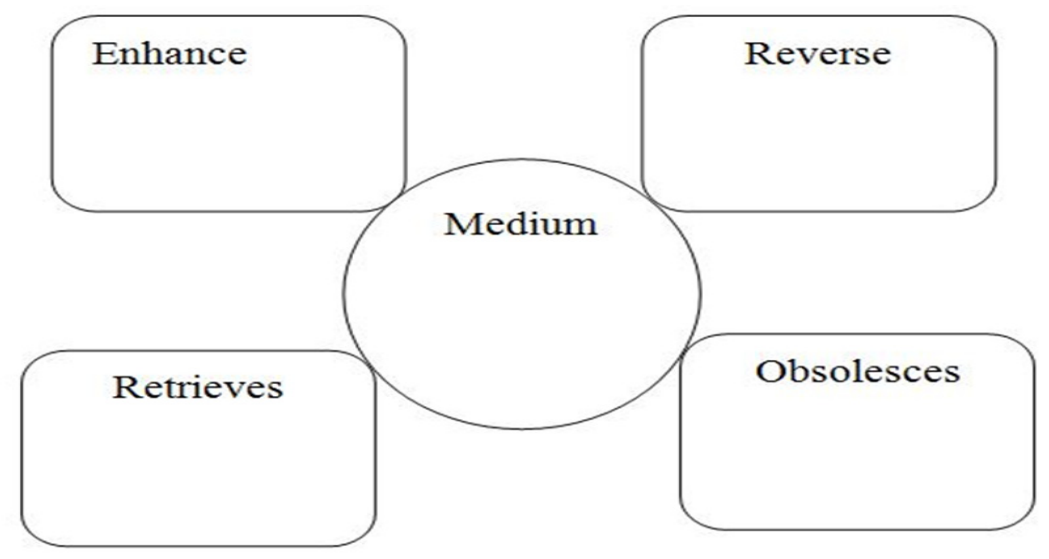

Figure 8. McLuhan's Media Theory (Source: Broughton et al., 2011)

Apart from that, Leonardi (2011) suggested that if the IT organisations use social media in developing the knowledge management system in business, they can easily transfer the result, content and materials. For instance, LinkedIn is the process of micro blogging service. Here people share their ideas related to their business through blog with 140 characters limit service. Sites where several managers of different company share their opinion and ideas related the professional blogging to different business. In addition, LinkedIn is the service of update news regarding business such as Microsoft announced to invest in Facebook.

Broughton et al. (2011) acknowledge that as several managers of different company from different region share the view in LinkedIn, IT organisations is able to realize the actual process of development of knowledge management system. Moreover, use of social media service allows the IT organisation to get new ideas of knowledge management and its benefits. Moreover, social media service allows the IT organisations in adopting the attitude of acceptance towards the behaviour and technologies.

\section{Conclusion}

This study aims to assess the relationship between the knowledge management system (KMS) and social media in IT organizations. In this regard, this study critically analysed the various models and theories related to knowledge management. This study is useful for both academia and practitioners as to fill the gap of the incomplete causal relationship between knowledge management and social media in IT organizations. Fundamentally, the capabilities of ICT knowledge management process if developed via social media tools allow the organizations to identify the loopholes and develop proper strategy to remove it. Hence, developing knowledge management process via social media brings a massive growth in business of IT organisations. Through social media, IT organisations are able to understand the accurate way of implement knowledge management system. It helps in future success of IT organisations and reduces the slow business process worldwide.

\section{References}

Abbasi, M. S., Tarhini, A., Elyas, T., \& Shah, F. (2015). Impact of individualism and collectivism over the individual's technology acceptance behaviour: A multi-group analysis between Pakistan and Turkey. Journal of Enterprise Information Management, 28(6), 747-768. http://dx.doi.org/10.1108/JEIM-12-2014-0124

Alalwan, A., Rana, N., Algharabat, R., \& Tarhini, A. (2016). A Systematic Review of Extant Literature in Social Media in the Marketing Perspective. In Conference on e-Business, e-Services and e-Society, Swansea, UK (13-15, Sep 2016). Springer International Publishing. http://dx.doi.org/10.1007/978-3-319-45234-0_8

Al-Busaidi, K. A. (2010). The Impact of Supporting Organizational Knowledge Management through a Corporate Portal on Employees and Business Processes. International Journal of Knowledge Management, 6(3), 44-64. 
http://dx.doi.org/10.4018/jkm.2010070103

Al-Busaidi, K. A., \& Olfman, L. (2005). An investigation of the determinants of knowledge management systems success in Omani organizations. Journal of Global Information Technology Management, 8(3), 6-27. http://dx.doi.org/10.1080/1097198X.2005.10856400

Al-Busaidi, K. A., Olfman, L., Ryan, T., \& Leroy, G. (2010). Sharing Knowledge to a Knowledge Management System: Examining the motivators and the benefits in an Omani organization. Journal of Organizational Knowledge Management, 201(25835), 1-12.

Al-Dmour, H., Al-Madani, S., Alansari, I., \& Al-Dmour, R. (2016). Factors Affecting the Effectiveness of Cause-Related Marketing Campaign: Moderating Effect of Sponsor-Cause Congruence. International Journal of Marketing Studies, 8(5), 20-41.

Alenezi, H., Tarhini, A., \& Sharma, S. K. (2015). Development of a Quantitative Model to Investigate the Strategic Relationship between Information Quality and e-Government Benefits. Transforming Government: People, Process and Policy, 9(3), 324-351. http://dx.doi.org/10.1108/TG-01-2015-0004

Alessandro, A., \& Ralph, G. (2009). Predicting Social Security numbers from public data. Proceedings of the National Academy of Sciences, 10(27), 10975-10980.

Al-Gharbi, K., Al-Kindi, A., \& Al-Salti, Z. (2009). IT/IS outsourcing from Omani organizations' perspective: Motivations and reservations. International journal of management innovation systems, 10(1), 1-15.

Almajali, D. A., Masa'deh, R., \& Tarhini, A. (2016). Antecedents of ERP Systems Implementation Success: A Study on Jordanian Healthcare Sector. Journal of Enterprise Information Management, 29(4), 549-565. http://dx.doi.org/10.1108/JEIM-03-2015-0024

Al-Salti, Z., \& Hackney, R. (2011). Factors impacting knowledge transfer success in information systems outsourcing. Journal of Enterprise Information Management, 24(5), 455-468. http://dx.doi.org/10.1108/17410391111166521

Al-Sarayrah, S., Obeidat, B.Y., Al-Salti, Z., \& Kattoua, T. (2016). The Effect of Culture on Strategic Human Resource Management Practices: A Theoretical Perspective. International Journal of Business Management and Economic Research, 7(4), 704-716

Altamony, H., Al-Salti, Z., Gharaibeh, A., \& Elyas, T. (2016). The relationship between Change Management Strategy and Successful Enterprise Resource Planning (ERP) Implementations: A Theoretical Perspective. International Journal of Business Management and Economic Research, 7(4), 690-703.

Anderson, C. (2009). The end of theory: The data deluge makes the scientific Method obsolete. Wired Magazine, 16(7), 16-07. http://dx.doi.org/10.1109/MTS.2009.932804

Arazy, O., Gellatly, I., Soobaek, J., \& Patterson, R. (2009). Wiki deployment in corporate settings. IEEE Technology and Society Magazine, 28(2), 57-64. http://dx.doi.org/10.1109/MTS.2009.932804

Barczyk, C., \& Duncan, D. (2011). Social Networking Media as a Tool for Teaching Business Administration Courses. International Journal of Humanities and Social Science, 1(17), 267-276.

Bohnert, D., \& Ross, W.H. (2010). The Influence of Social networking Web Sites on the Evaluation of Job Candidates. Cyperpsychology, Behaviour, and Social Networking, 13(3), 341-347. http://dx.doi.org/10.1089/cyber.2009.0193

Broughton, A., Higgins, T., Hicks, B., \& Cox, A. (2011). Workplaces and social networking: The implications for employment relations. IEEE Technology and Society Magazine, 6(2), 65-79.

Brown, V., \& Vaughn, D. (2011). The writing on the (Facebook) wall: The use of social networking sites in hiring decisions. Journal of Business Psychology, 2(2), 219-225. http://dx.doi.org/10.1007/s10869-011-9221-x

Brzozowski, M., Sandholm, T., \& Hogg, T. (2009). Effects of feedback and peer pressure on contributions to enterprise social media. Proceedings of the 2009 International Conference on Supporting Group Work (pp. 61-70). http://dx.doi.org/10.1145/1531674.1531684

Cater, T., \& Cater, B. (2009). Tangible Resources as Antecedents of a Company's Competitive Advantage and Performance. Journal for East European Management Studies, 14(2), 186-209.

Chamberlain, L. (2012). HR directors believe social media is ineffective for recruitment survey finds. Personnel Today, 4(1), 109-18 
Chaundry, A. S. (2009). Knowledge Management. Estonia: Tallinn University.

Chen, J., Geyer, W., Dugan, C., Muller, M., \& Guy, I. (2009). Make new friends, but keep the old: Recommending people on social networking sites. Proceedings of the 27th International Conference on Human Factors in Computing Systems, Miami, USA (pp. 201-210). http://dx.doi.org/10.1145/1518701.1518735

Chen, M., Huang, M. \& Cheng, Y. (2009). Measuring knowledge management performance using a competitive perspective: An empirical study. Expert Systems with Applications, (36), 8449-8459. http://dx.doi.org/10.1016/j.eswa.2008.10.067

Chu, S.K.W., \& Du, H. (2013). Social Networking Tools for Academic Libraries. Journal of Librarianship \& Information Science, 45(1), 64-75. http://dx.doi.org/10.1177/0961000611434361

CIPD. (2013). Social media and recruitment conference. London: Routledge.

Clark, L.A., \& Roberts, S.J. (2010). Employer's Use of Social Networking Sites: A Socially Irresponsible Practice. Journal of Business Ethics, 95(4), 507-525. http://dx.doi.org/10.1007/s10551-010-0436-y

Coakes, E., Amar, A.D., \& Luisa Granados, M.L. (2010). Knowledge management, strategy, and technology: a global snapshot. Journal of Enterprise Information Management, 23(3), 282-304. http://dx.doi.org/10.1108/17410391011036076

Contractor, N. (2009). The emergence of multidimensional networks. Journal of Computer Mediated Communication, 14(3), 743-747. http://dx.doi.org/10.1111/j.1083-6101.2009.01465.x

Dalkir, K. (2011). Knowledge Management in Theory and Practice. Cambridge, Massachusetts: the MIT Press.

Davison, H., Maraist, C., \& Bing, M. (2011). Friend or foe? The promise and pitfalls of using social networking sites for HR decisions. Journal of Business Psychology, 26(2), 153-159. http://dx.doi.org/10.1007/s10869-011-9215-8

Donovan, R., \& Henley, N., (2010). Principles and Practice of Social Marketing: An International Perspective. Cambridge University Press, London: UK. http://dx.doi.org/10.1017/CBO9780511761751

El-Masri, M., Orozco, J., Tarhini, A., \& Tarhini, T. (2015). The Impact of IS-Business Alignment Practices on Organizational Choice of IS-Business Alignment Strategies. The 19th Pacific Asia Conference on Information Systems (PACIS 2015), Paper 215, Singapore, 6-9 July 2015.

Fischer, E., \& Reuber, A. R. (2011). Social interaction via new social media: (How) can interactions on Twitter affect effectual thinking and behaviour?. Journal of Business Venturing, 26(1), 1-18. http://dx.doi.org/10.1016/j.jbusvent.2010.09.002

Fugate, B.S., Stank, T.P., \& Mentzer, J.T. (2009). Linking improved knowledge management to operational and organizational performance. Journal of Operations Management, (27), 247-264. http://dx.doi.org/10.1016/j.jom.2008.09.003

Hassouna, M., Elyas, T., \& Abou Trab, M. S. (2015). Customer Churn in Mobile Markets: A Comparison of Techniques. International Business Research, 8(6), 224-237. http://dx.doi.org/10.5539/ibr.v8n6p224

Heisig, P. (2009). Harmonisation of knowledge management - comparing $160 \mathrm{KM}$ frameworks around the globe. Journal of Knowledge Management, 13(4), 4-31. http://dx.doi.org/10.1108/13673270910971798

Holfve, M., \& Pekar, M. (2010). Knowledge Development: A Dual Perspective on Small Firms' Training and Development Needs. Sweden: Jankoping University

Kalkan, V.J. (2009). An overall view of knowledge management challenges for global business. Business Process Management Journal, 14(3), 390-400. http://dx.doi.org/10.1108/14637150810876689

Kaplan, A. M., \& Haenlein, M. (2010). Users of the world, unite! The challenges and opportunities of social media. Business Horizons, 53(1), 59-68. http://dx.doi.org/10.1016/j.bushor.2009.09.003

Koenig, M. (2009). Knowledge Management. Estonia: Tallinn University.

Lehner, F., \& Haas, N. (2010). Knowledge Management Success Factors - Proposal of an Empirical Research. Electronic Journal of Knowledge Management, 8(1), 79-90.

Leonardi, P. M. (2009). The implementation line: The mutual constitution of technology and organizing across development and use activities. Communication Theory, 19, 277-309. http://dx.doi.org/10.1111/j.1468-2885.2009.01344.x 
Leonardi, P. M. (2011). When flexible routines meet flexible technologies: Affordance, constraint, and the imbrication of human and material agencies. MIS Quarterly, 35, 147-167.

Li, C. (2010). Open Leadership: How Social Technology Can Transform the Way You Lead. San Francisco, CA: Jossey-Bass.

Maier, R., \& Thalmann, S. (2010). Using personas for designing knowledge and learning services: results of an ethnographically informed study. International Journal of Technology Enhanced Learning, 2(1/2), 58-74. http://dx.doi.org/10.1504/IJTEL.2010.031260

Masa'deh, R., Gharaibeh, A., Tarhini, A., \& Obeidat, B. (2015). Knowledge Sharing Capability: A Literature Review. In Fourth Scientific \& Research Conference on New Trends in Business, Management and Social Sciences, Istanbul, Turkey, 19-20 September 2015 (pp. 1-16). http://dx.doi.org/10.2139/ssrn.2696924

Masa'deh, R., Obeidat, B.Y., \& Al-Dmour, R.H. (2015). Knowledge Management Strategies as Intermediary Variables between IT-Business Strategic Alignment and Firm Performance. European Scientific Journal, 11(7), 344-368.

Masa'deh, R., Obeidat, B.Y., \& Tarhini, A. (2016). A Jordanian Empirical Study of The Associations Among Transformational Leadership, Transactional Leadership, Knowledge Sharing, Job Performance, and Firm Performance: A Structural Equation Modelling Approach. Journal of Management Development, 35(5), 681-705. http://dx.doi.org/10.1108/JMD-09-2015-0134

Masa'deh, R., Tarhini, A., Al-Dmour, R. H., \& Obeidat, B. Y. (2015). Strategic IT-Business Alignment as Managers' Explorative and Exploitative Strategies. European Scientific Journal, 11(7), 437-457.

Masa'deh, R., Tayeh, M., Al-Jarrah, I. M., \& Tarhini, A. (2015). Accounting vs. Market-based Measures of Firm Performance Related to Information Technology Investments. International Review of Social Sciences and Humanities, 9(1), 129-145.

Masa'deh, R., Shannak, R., Maqableh, M., \& Tarhini, A. (2016). The Impact of Knowledge Management on Job Performance in Higher Education: The Case of the University of Jordan. Journal of Enterprise Information Management, 29(6), 13-34.

Neto, R, C, D, de Alvarenga, Souza R, R, Queiroz J, G., \& Chipp H. (2009). Knowledge Management Implementation: a Process Design Proposition at Brazil's ONS (National Operator of the Interconnected Power System). Electronic Journal of Knowledge Management, 7(5), 593-604.

Nusair, K., Erdem, M., Okumus, F., \& Biligan, A. (2012). Users attitudes toward online social networks in travel. Social media in travel, tourism and hospitality: Theory, practice and cases. Farnham: Ashgate Publication.

Nusair, K., Yoon, H. J., \& Parsa, H. G. (2008). Effect of utilitarian and hedonic motivations on consumer satisfaction with travel websites. Information Technology \& Tourism, 10(1), 75-89.

Obeidat, B. Y., Hashem, L., Alansari, I., \& Al-Salti, Z. (2016). The Effect of Knowledge Management Uses on Total Quality Management Practices: A Theoretical Perspective. Journal of Management and strategy, 7(4), 12-33.

Obeidat, B.Y., Al-Sarayrah, S., Tarhini, A., Al-Dmour, R. H., \& Al-Salti, Z. (2016). Cultural Influence on Strategic Human Resource Management Practices: A Jordanian case study. International Business Research, 9(10), 22-39.

Obeidat, B.Y., Al-Suradi, M., Masa'deh, R., \& Tarhini, A. (2016). The Impact of Knowledge Management on Innovation: An Empirical Study on Jordanian Consultancy Firms. Management Research Review, 39(10), 11-27.

Orozco, J., Tarhini, A., Masa'deh, R., \& Tarhini, T. (2015). A framework of IS/business alignment management practices to improve the design of IT Governance architectures. International Journal of Business and Management, 10(4), 1-12. http://dx.doi.org/10.5539/ijbm.v10n4p1

Porumbeanu, O. L. (2010). Implementing Knowledge Management in Romanian Academic Libraries: Identifying the Elements that Characterize their Organizational Culture. Journal of Academic Librarianship, 36(6), 549-552. http://dx.doi.org/10.1016/j.acalib.2010.08.022

Ractham, P., \& Firpo, D. (2011). Using Social Networking Technology to Enhance Learning in Higher Education: A Case Study using Facebook. In Proceedings of the 44th Hawaii International Conference on System Sciences, Hawaii, USA (pp.1-10). http://dx.doi.org/10.1109/hicss.2011.479

Tarhini, A., Ammar, H., Tarhini, T., \& Masa'deh, R. (2015). Analysis of the Critical Success Factors for Enterprise 
Resource Planning Implementation from Stakeholders' Perspective: A Systematic Review. International Business Research, 8(4), 25-40. http://dx.doi.org/10.5539/ibr.v8n4p25

Tarhini, A., Arachchilage, N. A. G., Masa'deh, R., \& Abbasi, M.S. (2015). A Critical Review of Theories and Models of Technology Adoption and Acceptance in Information System Research. International Journal of Technology Diffusion (IJTD), 6(4), 58-77. http://dx.doi.org/10.4018/IJTD.2015100104

Thalmann, S. (2011). Decision Support Framework for Selecting Techniques to Prepare Knowledge Elements for Adaptive Use, Doctoral Dissertation, Austria: University of Innsbruck.

Zheng, Y., Li, L., \& Zheng, F. (2010). Social Media Support for Knowledge Management. Knowledge Creation Diffusion Utilization, 11(2), 9-12. http://dx.doi.org/10.1109/icmss.2010.5576725 